\title{
O CORPO DA MULHER COMO ACUMULAÇÃO DE SABEDORIA E RESISTÊNCIA NO POEMA "VIRGEM", DE LUIZA ROMÃO
}

\author{
THE BODY OF A WOMAN AS CUMULATIVE WISDOM AND \\ RESISTANCE IN THE POEM "VIRGEM", FROM LUIZA ROMÃO
}

Pilar Lago e Lousa (Unicamp) ${ }^{3}$

Flávio Pereira Camargo (UFG) ${ }^{4}$

\begin{abstract}
RESUMO: A obra poética de Luiza Romăo desvela a figura feminina sob a ótica da desconstruçâo da representaçâo clássica, permeada de mitos e tabus que através dos séculos foram utilizados para educar e controlar opressivamente os corpos das mulheres. Sabendo que a disciplinarizaçăo do corpo feminino obedece a um estereótipo que serve a grupos que controlam e detém posiçóes privilegiadas nas relaçóes de poder, propomos năo rechaçar o corpo, mas partir dele para desconstruir e dessacralizar sua representaçăo, que atualmente está alinhada às instituiçóes patriarcais vigentes. Neste sentido, este artigo tem como objetivo realizar um estudo acurado do poema "Virgem", do livro Coquetel Motolove (2014), a fim de verificar como as ferramentas poéticas e literárias possibilitam a desconstruçâo da representaçâo feminina tradicional e de que maneira o corpo feminino é visto como um lugar de acumulaçăo de sabedoria e resistência. As análises serâo efetuadas a partir das chaves interpretativas dos estudos feministas e de gênero. Para tal, serăo utilizados os arcabouços teóricos de Avtar Brah (2006), Elaine Showalter (1993; 2004), Elizabeth Grosz (2000), Michelle Perrot (2003), Pierre Bourdieu (2002), Rebecca Solnit (2017) e Silvia Federici (2017), entre outros.
\end{abstract}

PALAVRAS-CHAVE: Poesia contemporânea. Autoria feminina. Estudos de gênero. Corpo e resistência. Luiza Romáo.

1 O poema em questăo foi publicado no livro Coquetel Motolove sem título, mas foi amplamente difundido das redes sociais com o nome de "Virgem". Por uma questăo de nomenclatura e para mais fácil mencionálo, utilizaremos o título em questăo.

2 The abovementioned poem was published without a title in the book Coquetel Motolove, but has been highly widespread in the social media with the name "Virgem" [Virgin (free translation)]. As for nomenclature and easier mentions, we shall use the title in question.

3 Doutoranda em Teoria e História Literária do Instituto de Estudos da Linguagem, Unicamp, Campinas SP, Brasil. Orientanda da professora Dra. Suzi Frankl Sperber. e-mail: pilarbu@gmail.com.

4 Professor Adjunto de Literatura Brasileira da Faculdade de Letras da Universidade Federal de Goiás, com atuaçâo na Graduaçâo e no Programa de Pós-Graduaçâo em Letras e Linguística. E-mail: camargolitera@ gmail.com 
ABSTRACT: The poetry of Luiza Romano reveals the feminine figure from a classic representation deconstruction point of view, permeated by myths and taboos that through the centuries have been used to oppressively educate and control the bodies of women. Aware that the disciplinarization of the female body obeys a stereotype that serves groups which control and detain privileged positions in power relations, we propose not to reject the body, but from its standpoint, deconstruct and desecrate its representation, which is currently aligned to the patriarchal institutions in place. Thus, this article has the purpose of performing an accurate study of the poem "Virgem", from the book Coquetel Motolove (2014), in order to verify how the poetic and literary tools enable the deconstruction of the traditional female representation and how the female body is seen as a place of cumulative wisdom and resistance. The analyses shall be made from key interpretations of gender and feminism studies. For such, the following authors shall be used as theoretical background: Avtar Brah (2006), Elaine Showalter (1993; 2004), Elizabeth Grosz (2000), Michelle Perrot (2003), Pierre Bourdieu (2002), Rebecca Solnit (2017) and Silvia Federici (2017), among others.

KEYWORDS: Contemporary poetry. Female authorship. Body and resistance. Gender studies. Luiza Romáo

porque uma mulher braba nâo é uma mulher boa

e uma mulher boa é uma mulher limpa

Angélica Freitas

\section{LUIZA ROMÃO E A PALAVRA EM ESTADO DE LANÇA}

Luiza Romáo nasceu em 8 de agosto de 1992, em Ribeirăo Preto, é poeta, atriz e slammer. Ainda que advinda de uma família de intelectuais (seus pais săo professores) esteve desde muito nova ligada às causas dos direitos elementares, como os assentamentos do MST - Movimento dos Sem Terra. Mudou-se para a capital de Sáo Paulo para fazer graduaçăo e formou-se bacharel em Artes Cênicas (Direçâo). Nesse período percebeu que para além da universidade, um ambiente muitas vezes elitista, precisava encontrar seu lugar no mundo. Foi no último semestre de faculdade, que integrando um grupo de teatro, a autora fez um estágio na Fundaçăo Casa ${ }^{5}$, desenvolvendo uma peça para aquele público. Ali se construía uma nova perspectiva sobre sua arte e a maneira como, segundo a autora, poderia usar seus privilégios para mudar alguma coisa na sociedade ${ }^{6}$.

5 Fundaçâo Centro de Atendimento Socioeducativo ao Adolescente (CASA) presta atendimento a jovens de 12 a 21 anos incompletos do estado de Sáo Paulo e aplica medidas socioeducativas de privaçáo da liberdade (internaçăo) e semiliberdade.

6 Informaçôes coletadas em entrevista presencial concedida pela poeta Luiza Romăo em 24 de julho de 2017 
Durante o ano de 2013, a autora conheceu o Sarau do Burro, ficou encantada e passou a ser assídua. Já ao final daquele mesmo ano teve o primeiro contato com a cena do slam e a identificaçáo foi imediata. Luiza Romáo percebeu que era aquele tipo de arte engajada, preocupada com o contexto social, que propóe trazer para o espaço público o debate das mazelas sociais compartilhadas pelos conflitos e tensōes que se inscrevem na cidade, que ela queria se vincular. Encontrara seu lugar como artista, como poeta, no mundo?.

O ano de 2014 consagrou Luiza Romáo. A poeta ganhou o Slam da Guilhermina, o Slam do 13 e foi a vice-campeâ nacional do Slam BR, campeonato Nacional de Poesia Falada. O pertencimento experimentado por Luiza Romáo a legitimou na cena do slam e da literatura marginal-periférica, colocou-a num espaço de afeto que hoje a faz ser considerada uma das mais importantes e expressivas slammers da cena paulistana.

Os slams, assim como os saraus, săo movimentos de poesia falada inscritos sob a rubrica da literatura marginal-periférica, rasuram a tradiçâo literária canônica devolvendo a arte poética para o espaço público, para as máos de pessoas comuns. Ainda que nâo exista uma obrigaçăo temática, o que se verifica é uma estética do grito, um grito que rompe silêncios, que toma posse da autorrepresentaçăo tradicionalmente negada, que desloca o olhar crítico para periferias e grupos minoritários, que pauta um viés político que denuncia e deflagra as mais diversas formas de violência simbólica, de gênero e física que atravessam nossa sociedade.

Coquetel Motolove 8 foi lançado em 2014 com urgência e atendia a uma necessidade de Luiza Romáo se colocar no mundo também com um livro, năo apenas na oralidade. 0 livro traz o verso como arma, projétil que toca nas feridas mais profundas. O potencial bélico da escrita permeia a concepçâo da obra, passando do título e capa até chegar na construçăo poética de versos que transpiram rebeldia e contundência.

Este artigo tem como objetivo realizar um estudo acurado do poema "Virgem", a fim de verificar como as ferramentas poéticas e literárias possibilitam a desconstruçâo da representaçăo feminina tradicional e de que maneira o corpo feminino é visto como um lugar de acumulaçâo de sabedoria e resistência. A escolha do poema se deve a dois fatores: o primeiro está ligado à construçâo histórica da autora, pois ele foi um dos poemas que a ajudou a ganhar o Slam da Guilhermina em $2014^{9}$ e consequentemente conseguir uma vaga no SLAM BR, do qual foi vice-campeá no mesmo ano. O segundo fator fundamental para a escolha da análise desse poema é por trazer a problematizaçấo contundente de certos mitos e tabus e formas de violência que oprimem mulheres. A autora faz um movimento primeiro descontrói para depois construir poeticamente uma outra mulher, mais empoderada e emancipada. As análises serâo efetuadas pela chave interpretativa dos estudos de gênero e feministas.

7 Informaçóes coletadas em entrevista presencial concedida pela poeta Luiza Româo em 24 de julho de 2017.

8 Apesar de, na grafia da capa do livro, constar Coketel (com K), tanto na ficha bibliográfica do livro quanto na página da autora nas redes sociais, a grafia aparece como Coquetel (com "q" e "u"). Por isso, a segunda opçāo foi a utilizada neste estudo.

9 A apresentaçăo de Luiza Romáo na final do Slam da Guilhermina na íntegra está disponível em: https:// www.youtube.com/watch?v=7RRiuGys8AE. Acesso em 20 out. 2016. 


\section{A DEMONIZAÇÃO DO FEMININO COMO FORMA DE CONTROLE DAS MULHERES}

Por que o corpo da mulher ainda provoca tanto medo e desconfiança? Por que o feminino é cercado de tantos tabus sexuais, discursivos e sociológicos? Por que disputar o discurso em uma sociedade balizada em estruturas patriarcais é tâo extenuante e difícil para as mulheres?

Resgatar os estudos feministas sobre o corpo da mulher, sua fisicalidade e o lugar de sua representaçấo dentro da literatura e da sociedade se faz de suma importância para compreender suas demandas. É também um importante instrumento de desconstruçáo das estruturas patriarcais opressoras e de problematizar práticas sociais e literárias que se configuram como excludentes.

No livro 0 Calibâ e a Bruxa (2017), Silvia Federici faz um apanhado histórico a fim de verificar de que maneira a institucionalizaçâo do capitalismo cumpriu um projeto político e social que visava controlar e domesticar mulheres. $O$ entendimento do indivíduo como máquina, essencial para a designaçáo produtiva do trabalho, tornou necessária a polarizaçăo entre razăo e corpo, a fim de dominar as paixóes, promover o autocontrole e instaurar o senso de responsabilidade.

Dentro dessa perspectiva, as mulheres foram as que mais sofreram, segundo a autora, visto que elas detinham o conhecimento pagâo por meio da conexăo com a natureza, era delas até entâo o controle reprodutivo e consequentemente do crescimento da populaçăo. Nos estudos de Silvia Federici (2017), estado e igreja se uniram para garantir năo apenas o aumento da populaçăo, e consequentemente a criaçăo de força de trabalho, mas também na manutençăo do alinhamento à cultura judaico-cristă, da garantia do acesso à terra pelas classes dominantes, da subalternizaçâo de mulheres e das camadas mais pobres, e da instauraçấo das relaçóes patriarcais pautadas nas diferenças sexuais.

Nesse cenário, a caça às bruxas cumpriu um importante papel de controle social e populacional, configurando-se como uma "tentativa de criminalizar o controle da natalidade e de colocar o corpo feminino - o útero - a serviço do aumento da populaçăo e da acumulaçăo da força de trabalho" (FEDERICI, 2017, p. 326). Parecia ser o jeito mais eficaz da burguesia controlar o patriarcado. A caça às bruxas mandou à forca e às fogueiras mulheres consideradas dissidentes, seja pelo conhecimento e manipulaçáo da natureza, seja pela discordância das políticas empregadas pelo status quo da época, seja por nâo seguirem os padrōes de comportamento vigente, seja por năo se assujeitarem a ter sua sexualidade e corpo controlados deliberadamente pelo estado e pela igreja.

Elizabeth Grosz salienta no artigo "Corpos Reconfigurados" que a filosofia ocidental dominante pautou seu pensamento na dicotomia e polarizaçăo entre

mente e corpo, pensamento e extensăo, razăo e paixăo, psicologia e biologia. Esta bifurcaçấo do ser năo é simplesmente uma divisăo neutra de um campo descritivo abrangente. $O$ pensamento dicotômico necessariamente hierarquiza e classifica os dois termos polarizados de modo que um deles se torna o termo privilegiado e o outro sua contrapartida suprimida, subordinada, negativa (GROSZ, 2000, p. 47). 
Assim a razâo se sobrepóe ao outro, que é o corpo, subalternizando na maioria das vezes o conhecimento e aprendizado advindos dele. É importante salientar que nessa polarizaçăo os homens passaram a ser representados pela racionalizaçâo, enquanto as mulheres seriam relegadas apenas ao reduto do corpo (GROSZ, 2000, p. 49). A teoria biologizante reduz mulheres apenas à sua constituiçâo física e biológica, ao seu dever quase sagrado de reproduçăo, recusando seu corpo como espaço simbólico de acumulaçăo de sabedoria e memória, de disputa de discurso. A medicalizaçăo e a abjeçấo do corpo feminino retira delas o controle sobre sua fisicalidade, seus desejos, retiram também a potência de seus afetos, a capacidade de se deslocarem, de praticarem a açáo e serem sujeitos de suas próprias vidas.

A ideologia judaico-cristă, os modelos de corpo naturalizados pela filosofia ocidental e o cartesianismo instituíram normas de conduta que procuram controlar, domesticar e dominar mulheres em detrimento dos homens. Segundo Guacira Lopes Louro, "um corpo escolarizado é capaz de ficar sentado por horas e tem, provavelmente, a habilidade para expressar gestos ou comportamentos indicativos de interesse e de atençâo, mesmo que falsos" (2010, p. 21).

Sabendo que a disciplinarizaçấo do corpo feminino obedece a um estereótipo que serve a grupos que controlam e detém posiçōes privilegiadas nas relaçōes de poder, propomos năo rechaçar o corpo, mas partir dele para desconstruir e dessacralizar sua representaçăo, que atualmente está alinhada às instituiçóes patriarcais vigentes. Assim, o útero, a vagina, os excrementos e tudo aquilo que os cercam seriam molas propulsoras de discursos contra-hegemônicos, pautados na ruptura de certos paradigmas e tabus. Esses elementos, agora ressignificados, também estariam alinhados à noçâo de que os corpos, além de sistemas biológicos, săo construçōes estéticas, políticas e sociais.

\section{DESOBEDIENTE, INSUBMISSA E BRUXA}

A mulher bruxa, que se casa e se deita com o diabo, revelou ser o estereótipo perfeito para a criminalizaçâo dos desejos, do corpo e da sexualidade femininos. Capaz de seduzir e desvirtuar o mais ilibado dos homens, essa mulher força da natureza precisava ser subjugada visto que representava "uma ameaça à ordem social, já que subvertia o sentido de responsabilidade dos homens e sua capacidade de trabalho e autocontrole" (FEDERICI, 2017, p. 343). Em oposiçăo a essa mulher diabólica, profana, incontrolável, que engolia e castrava homens estabeleceu-se a figura feminina sagrada, presente nas escrituras bíblicas e materializada pela mulher imaculada, resiliente, subserviente, que seria a mâe perfeita de todos, a virgem Maria.

A virgindade passou a ser pontuada como uma virtude, uma característica que distinguia mulheres boas de mulheres más. O poema de Luiza Romáo que corroborou para que ela fosse consagrada vencedora do Slam da Guilhermina em 2014 traz essa temática. Em Coquetel Motolove, o poema originalmente intitulado "Virgem", mas que no livro teve o título suprimido, propōe um olhar crítico para essa questăo. E vai além, ao problematizar o que vem a ser uma mulher para os padróes estabelecidos pelas estruturas patriarcais.

Se o corpo é o lugar de enunciaçăo "nossas vozes săo aspectos essenciais da nossa humanidade, ser privado de voz é ser desumanizado ou excluído da sua humanidade. E 
a história do silêncio é central na história das mulheres" (SOLNIT, 2017, p. 28). Assim a recuperaçấo da corporeidade feminina é também o resgate da voz que se liberta.

A epígrafe traz os seguintes dizeres: "este texto năo é um texto. este texto é um parto:/ tem a dor do que parte, do que fica, do que nasce" (ROMÂO, 2014, p. 21). Ao usar a palavra "parto", Luiza Romăo inicia o poema deflagrando o processo de gerir e alimentar uma outra vida, que năo destaca apenas filhos ou biologia, mas principalmente o potencial criativo, poético e estético oriundo do corpo e da escrita desse eu lírico feminino. Ressalta ainda a importância da existência e da persistência da dor, que perpassa todas as alternativas que possam vir a ser escolhias: ficar, ir embora e nascer. Ser mulher invariavelmente dói.

Ao utilizar elementos puramente biológicos como força do objeto crítico, podemos depreender também que a poeta rechaça a própria teoria biologizante, que é largamente utilizada para marcar a inferioridade feminina.

\author{
ser virgem \\ está muito além de um hímen \\ da palavra ser ou năo ter hífen \\ é matéria-prima \\ barro úmido \\ húmus: \\ human woman women (ROMÅO, 2014, p. 21)
}

Usada através dos tempos para controlar e dominar os corpos femininos, a virgindade como sinônimo de pureza e respeito é questionada nesses versos. Ser virgem está além da existência ou năo do hímen por que ser mulher está muito além de ser virgem, desse ritual de passagem que comprova e reafirma a transformaçâo de meninas em possíveis măes, produtivas e reprodutivas.

Resgatando os estudos de Simone de Beauvoir (2009 p. 361), podemos verificar que repousa sobre a mulher uma teoria tradicional baseada na biologia que a reduz a uma concepçâo de mera procriadora da humanidade. A célebre frase "nâo se nasce mulher, torna-se" vem acompanhada da afirmaçăo de que "nenhum destino biológico ou psíquico ou econômico define a forma que a fêmea humana assume no seio da sociedade", o que existe é um processo cruel de socializaçăo que subalterniza o feminino em detrimento do masculino. O masculino, por construtos sociais enraizados, nos é apresentado tradicionalmente como o ser perfeito, nâo castrado.

Segundo Michelle Perrot, essas sociabilizaçōes e construçōes balizam o corpo feminino como símbolo de inferioridade e subalternizaçăo visto que

as representaçōes do corpo feminino, tal como as desenvolve a filosofia grega, por exemplo, assimilam-no a uma terra fria, seca, a zona passiva, que se submete, reproduz, mas nâo cria, que nâo produz nenhum acontecimento nem história e do qual, consequentemente nâo há nada a dizer (PERROT, 2003, p. 20). 
Ao afirmar que ser virgem está além das construçôes sociais e das normas de conduta, por meio dos versos "é matéria-prima", "barro úmido", o eu poético subverte a lógica da filosofia grega e evidencia o poder de criaçáo, de construçáo do corpo da mulher, ao passo que coloca em cheque a alegoria do ser feminino como o sujeito física e socialmente mutilado, desprovido de relevância. Devolve para as máos da mulher o poder de praticar a açâo ao complementar:
homem,
eu não nasci da sua costela
vim ao mundo pelas mãos
de alguma obstetra
filha de mãe mulher donzela
não.
sou filha da outra
a que tem suor, sangue e leite
a que labuta com dois filhos nas costas
e um no peito (ROMÃO, 2014, p. 21)

não da bela-pequena-aurora-adormecida-sereia-de-chapéu-vermelho,

Eva, nascendo da costela de Adâo, cometendo o pecado original ao morder a maçá, condenando todas as mulheres filhas de Eva a estarem para sempre marcadas pela culpa e pela perversăo. Eva que desgraçou a humanidade com sua impureza e flertou com o diabo, demonizando a sexualidade feminina. Ao dizer que náo nasceu da costela do homem, o eu poético rompe e contrapóe a esse modelo de controle do corpo das mulheres, subverte e critica a Cultura judaico-cristá e estabelece um outro paradigma de reconhecimento e representaçáo do feminino. Em resposta à essa visăo higienista e romantizada, essa mulher em franca libertaçăo, afirma que nasceu pelas máos de outra mulher, uma obstetra que lhe deu a vida, uma cientista longe dos padróes religiosos eurocentrados.

E se ela náo nasceu de um homem, também năo é a figura feminina eurocêntrica que comprova sua ascendência. Ela nâo é filha de uma mulher que cumpre os pré-requisitos dos padróes impostos socialmente, aqui evidenciados pelo resgate dos autos de moralidade caracterizados pela Bela adormecida, Pequena sereia e Chapeuzinho vermelho. Ao evocar as personagens eternizadas pelos estúdios Disney, três críticas podem ser percebidas: à alienaçấo produzida pelos veículos de massa, que tem como objetivo controlar as mulheres; aos padróes inatingíveis exigidos pelo mito da beleza; e por fim ao cânone literário de tradiçăo oral que também tinha a funçăo de normatizar negativamente a conduta de mulheres com os autos de moralidade.

Ao deixar claro que é filha da outra, da considerada abjeta, o eu poético coloca em contraposiçâo o que se espera socialmente da figura feminina com o que se configura de fato, na realidade. Avtar Brah evidencia que os movimentos feministas "năo ignoram a biologia das mulheres, mas questionam ideologias que constroem e representam a subordinaçăo das mulheres como resultado de suas capacidades biológicas" 
(BRAH, 2006, p. 342) Por isso, ao reverter os líquidos produzidos pelo corpo feminino em positividade, Luiza Romáo rompe com estéticas patriarcais misóginas e materializa a representaçăo de uma măe mais próxima da realidade, năo aquela cuja pureza, castidade e feminilidade săo vistas como virtudes. Nâo aquela que espera ser salva. 0 suor se torna sinônimo de trabalho, o sangue a representaçāo da luta e o leite é o símbolo da vida, marcas do corpo que a princípio săo da ordem da biologia se transformam em inscriçôes de resistência e de existência que as materializa no mundo por meio de um discurso transgressor.

Nâo estamos falando de qualquer mulher, mas de uma mulher com "labuta com dois filhos nas costas"/ "e um no peito", uma mulher em constante luta, a quem năo foi dado o direito de ser frágil, de aguardar ser salva por um homem. A história das mulheres populares náo coaduna com essa representaçâo clássica de mulheres frágeis, delicadas e destinadas ao recato, visto que trabalhavam e muito, chefiando famílias e tendo de lidar constantemente com históricos de abandono.

Uma mulher que precisa fazer malabarismos para dar conta dos filhos, do trabalho e de suas demandas pessoais. Uma mulher periférica, tradicionalmente subalternizada, que precisa ainda mais disputar o espaço político e simbólico de sua fisicalidade. A quem năo foram dados os privilégios sociais que garantem uma vida mais tranquila e menos dolorosa.

Ao resgatar e exaltar esse modelo feminino contra-hegemônico, a poesia de Luiza Romáo coloca essa mulher como esteio e referencial concreto para o empoderamento daquelas que a ela se identificam, que compartilham de suas experiências e lutas. E se năo é pela subalternizaçăo frente aos homens que se torna mulher, também năo o é pela cultura falocêntrica:

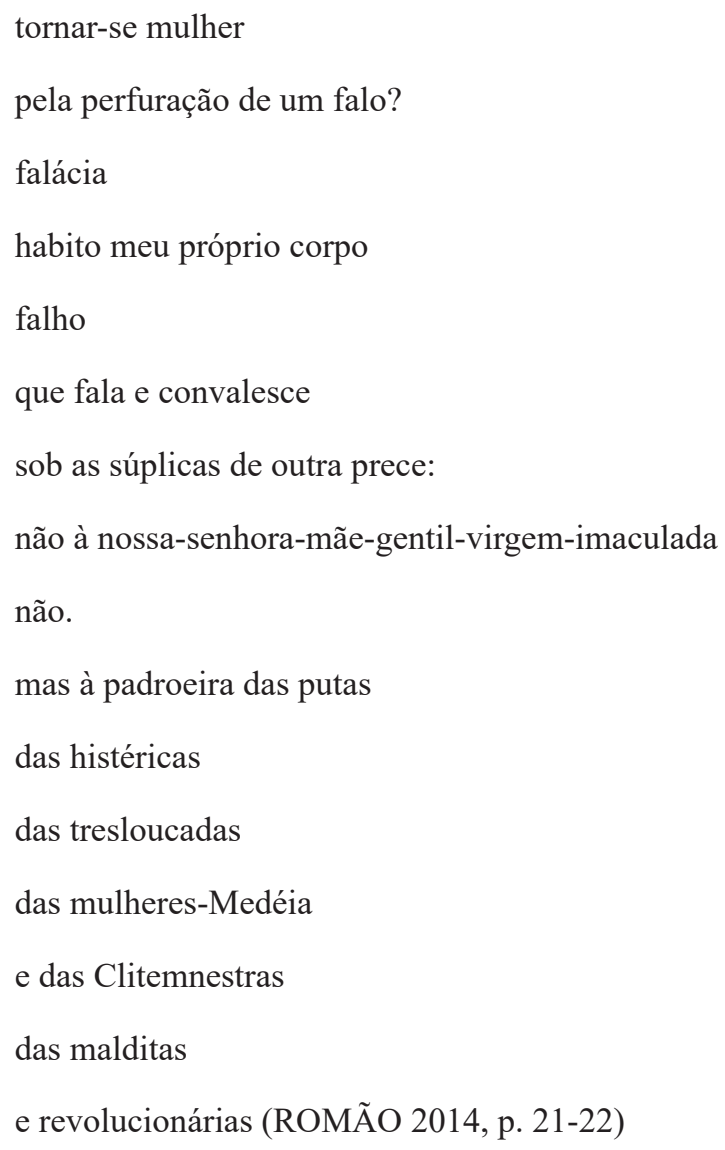


Bourdieu, em seu livro A dominaçâo masculina, evidencia que o corpo é uma construçáo cultural e social e a "ordem social funciona como uma imensa máquina simbólica que tende a ratificar a dominaçâo masculina sobre a qual se alicerça" (2002, p. 18). Este espaço discursivo, que também é simbólico, configura-se como um campo onde se travam lutas, e que estas por sua vez se revelam nas relaçōes de poder. Nele, através dos séculos e por meio do habitus, os homens imputaram às mulheres as mais variadas formas de opressăo e violência, entre elas a física e a simbólica.

Ao recusar o rito de passagem da perda da virgindade como um legitimador único da existência do feminino, que transformaria a menina pura em uma mulher hábil para a reproduçăo, Luiza Romăo rechaça a representaçăo filosófica grega que postula que "o princípio da vida, da açấo, é o corpo masculino, o falo, o esperma que gera, o pneuma, o sopro criador" assim como também subverte a simbologia do útero como "cavernoso, oculto, matricial", que deve ser subtraído, "um abismo sem fundo no qual o homem se esgota, deixa sua forca de vida" (PERROT, 2003, p. 20 - 21). Ao contrário, ela exalta a representaçăo feminina para além da abjeçăo.

Nesta estrofe, Luiza Romáo procurar romper com a lógica da dominaçăo masculina. Ao dizer que habita o próprio corpo, a figura feminina inverte as posiçóes dentro desse campo de batalha, revela que náo será mais subjugada pela estrutura da máquina patriarcal que configura a sociedade como um espaço de dor para as mulheres, baseado na concepçâo de que o falo e o corpo masculino sâo dominantes e tem mais valor.

Ao se contrapor à dominaçăo masculina, o eu lírico feminino aceita a imperfeiçăo, por meio da palavra "falho" e rechaça os padróes, evidenciando que suas preces nâo serâo dirigidas à evocaçâo da normatizaçâo judaico-cristâ. Por meio da antítese e contrapondo estereótipos, rogará que suas súplicas sejam ouvidas e atendidas pelas representaçôes femininas consideradas abjetas como as putas, que tiveram a humanidade de seus corpos esvaziadas pelos padrôes morais.

Ao trazer para a poesia a figura das histéricas e tresloucadas, Luiza Româo faz uma crítica à medicina e à medicalizaçăo de mulheres que internou e tirou do convívio social aquelas que pareciam estar acometidas por um mal súbito feminino. A palavra hystera significa útero em latim e a histeria como doença pautou, em princípio, a concepçăo de que o "útero, faminto, percorria o corpo livremente" (SHOWALTER, 2004, p. 33) e produzia os mais diversificados sintomas. Showalter afirma que quando os anatomistas descobriram que o útero năo migrava responsabilizaram o sistema nervoso das mulheres pela doença, mas foi apenas no século XVII que a medicina reconheceu que os homens também podiam ser vítimas e estarem sujeitos à histeria (SHOWALTER, 2004, p. 33).

Entretanto, o estereótipo do feminino como sendo o sexo nervoso, melancólico e erotizado por esse útero insaciável já estava posto e foi amplamente difundido pela mídia e pelos de comunicaçâo de massa. Segundo Showalter (2004, p. 43), a perspectiva da histeria também está intimamente ligada à noçáo da caça às bruxas, instituindo o corpo feminino como o grande inimigo a ser abatido, controlado, exorcizado e convertido pelas instituiçóes religiosas e patriarcais.

Assim, as mulheres eram internadas pelos mais diversos motivos sob a desculpa de estarem severamente doentes, mas o que se verifica é de fato a necessidade de controlar aquelas que se configuravam como dissidentes, subversivas ou que demonstravam 
ser algum tipo de entrave para que os homens atingissem seus objetivos de poder. Ao evocar essa representação feminina desencaixada dos padróes e normas, Luiza Romáo afirma, de certa forma, que năo se deixarâo reprogramar para cumprir os papéis tradicionais.

Semelhante movimento faz a poeta ao resgatar Medéia e Clitemnestra. Trazê-las para o poema mostra a formaçấo de atriz de Luiza Româo e o resgate da literatura grega, visto que Medéia é uma tragédia grega composta pelo poeta Eurípedes; enquanto Clitemnestra está presente na trilogia teatral Orestia, do dramaturgo grego Esquilo.

As duas săo figuras clássicas da ordem dos mitos que năo cumpriram como se esperava o papel tido como sagrado das măes e estabelecem uma contraposiçấo com a figura maculada da virgem Maria que aparece no início do poema. Elas săo lidas comumente como feiticeiras capazes das maiores atrocidades, falharam como esposas e seus mitos questionam a maternidade compulsória e o sagrado amor de măe.

Na tragédia grega de Eurípedes, Medéia mata os próprios filhos em vingança à traiçâo do marido Jasăo, a quem dedicara todo amor e devoçâo. No teatro de Ésquilo, a trama complexa enredada por Climtemnestra revela uma mulher com habilidade para articular e premeditar vingança. As duas personagens podem ser consideradas proto-feministas, visto que suas histórias pessoais deflagram e denunciam a misoginia, a supremacia masculina e certas relaçôes patriarcais que as tornam prisioneiras da situaçăo em que vivem.

Por fim, as malditas e revolucionárias trazem novamente a imagens das bruxas que queimaram na fogueira por ter uma visăo à frente do seu tempo. Ao trazer para a ordem do poético personagens que romperam a tradiçâo deflagra a luta diária da poesia que desconstrói a ordem do literário, o que se espera da representaçấo tradicional. E assim a presença da voz viva que resgata vozes do passado atualiza uma invasâo do presente e permite a constituiçăo de um novo tecido memorial (D'ALVA, 2014, p. 126) que possibilita o diálogo de múltiplas vozes femininas que se reconhecem na diferença, nas lutas e nas diversas disputas de discurso.

Ao fazer esse movimento de resgatar mulheres que năo se calaram e romperam paradigmas, a poesia de Luiza Romăo propôe a constituiçấo de uma coletividade, de um processo de empatia que envolve tanto essas mulheres, quanto o leitor e/ou receptor (no caso da poesia oral) quanto a própria autora. Essa funçấo coletiva se alinha a noçâo da circulaçấo das economias afetivas, como postulada por Sara Ahmed, e conclama a mulher comum a também nâo se deixar assujeitar. Revela-se assim um processo de empoderamento e emancipaçăo, em que o feminino como sujeito do discurso tem o poder efetivo da mudança. Esse sentimento de empoderamento e coletividade atua com um afeto vinculado ao desejo e à esperança que movimenta o engajamento político em torno dos movimentos feministas (AHMED, 2003, p. 251).

As próximas estrofes conclamam meninas e mulheres a subverterem estereótipos e controlarem seus corpos, denunciando estéticas literárias, políticas e sociais que revelam práticas cruéis: 
meninas em gestação

de ser mulher

meninas que sangram

mês a mês

possibilidades de si

que abortam o que não teve lugar

o que não pode ser

meninas em gestação

mulheres em gesto e ação

não colocarei o pau na mesa

se você vem com

'porra, porrada, caralho'

mostro meus peitos abertos

meus seios e anseios fartos dessa gramática de barbárie (ROMÃO, 2014, p. 22)

Segundo Elaine Showalter através dos séculos perpetuou-se a ideia de que o órgáo sexual feminino é uma regiăo inóspita, um espaço interditado, proibido, regido pelo mito da vagina dentada que se configura como um "espectro da sexualidade feminina, uma boca silenciosa, porém terrível, que pode ferir ou devorar o observador masculino" (SHOWALTER, 1993, p. 194). Essa boca capaz de castrar homens e subjugá-los precisava ser controlada socialmente e por isso lançou-se um véu em cima dela e de tudo que a cerca. Assim, tudo que vem do corpo da mulher passou a ser considerado abjeto: excrementos, menstruaçăo, sexualidade, libido, desejo.

Em Coquetel Motolove esse véu é retirado da vagina dentada, do útero faminto e o corpo feminino năo habita mais uma regiăo inóspita, em que o silenciamento compulsório impera. $O$ aparelho reprodutivo como representaçăo da opressâo é aqui desconstruído de diversas formas. A menstruaçăo aparece nesse poema nâo como fardo ou impossibilidade e sim como oportunidade de repensar e ressignificar o próprio eu.

Segundo Márcia Tiburi, a criminalizaçăo do aborto em uma sociedade patriarcal é a metáfora perfeita para o moralismo e que corrobora com discursos masculinistas em que a mulher é um mero receptáculo, fêmea submetida à natureza e de quem o prazer é retirado, aquela que cumpre a funçâo sagrada de ser mâe (TIBURI, 2017). Quando o poema subverte essa lógica do discurso opressor e evidencia o aborto como uma prática de expurgo do "que năo teve lugar/o que năo pode ser", revela-o como continuidade da experiência de conhecimento do próprio corpo. O aborto é apresentado como ferramenta de expurgo náo apenas do feto indesejado, mas também de tudo aquilo que náo configura, năo define uma mulher, tudo aquilo que a oprime e torna essas figuras femininas despertencidas de si. O eu lírico devolve o poder da mulher controlar o próprio 
corpo em detrimento de um discurso de castraçăo e subalternidade.

O eu poético evidencia essas meninas, que ainda estāo se preparando para se tornarem mulheres, mas que já sentem o peso e as cobranças que as marcam, desde o nascimento. O jogo semântico entre as palavras gesto e açăo, para compor o novo significado de gestaçâo marca, de maneira muito pungente a resistência da poesia de Luiza Romáo. A desconstruçâo do sangramento outrora tido como doença revela a transformaçâo da representaçăo feminina que deixa de estar aprisionada em perspectivas higienistas e medicalizadas para vincular-se à estéticas de empoderamento e emancipaçâo. A menstruaçáo é utilizada como mais uma ferramenta de luta e resistência: meninas que estăo em processo de se tornarem adultas ainda mais libertas e conscientes de seus corpos e suas reais necessidades.

Sendo assim, a visăo rasa, galgada na teoria biológica, amplamente difundida na sociedade patriarcal, que rechaça mulheres em função de sua constituiçâo física nâo se sustenta, em virtude da imensa gama de possibilidades de representaçấo. Uma mulher nâo é apenas uma esposa, mâe, prostitua ou objeto de desejo, mas como na imagem de um prisma, tem muitas facetas, podendo ser todas ou nenhuma:

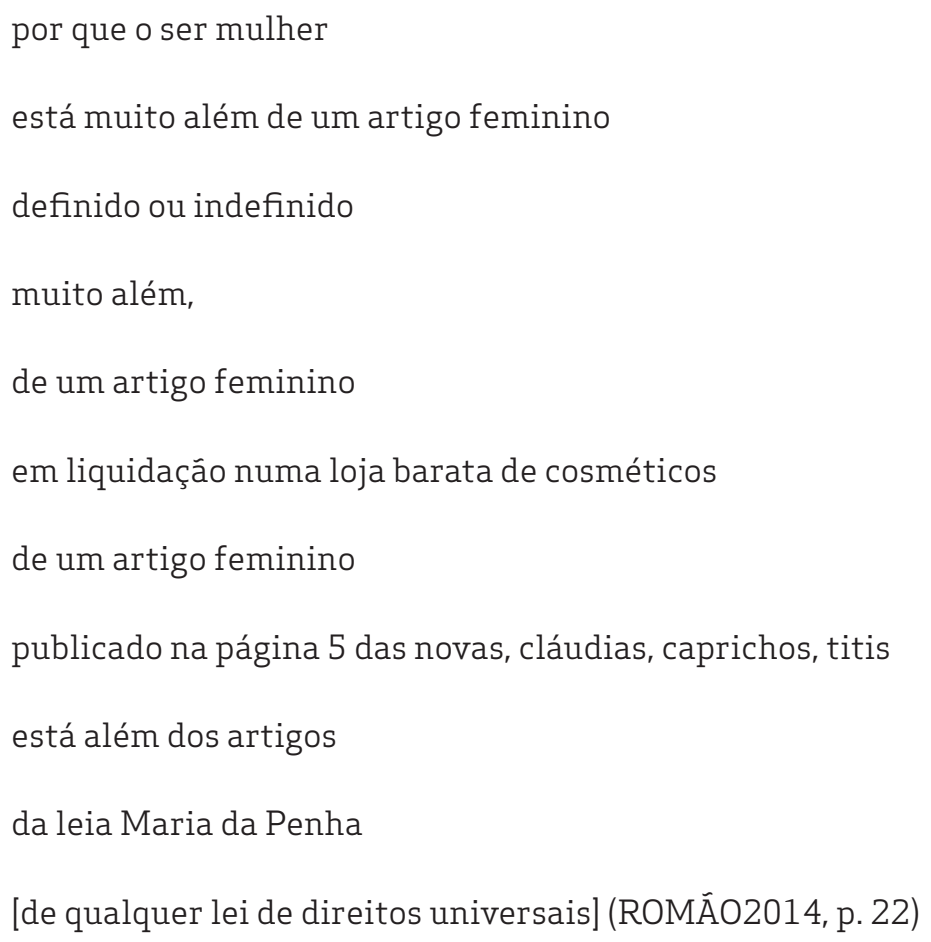

A palavra artigo materializa a figura feminina e ganha neste poema, por meio das sucessivas anáforas, mais de um sentido, todos configurados como pejorativos e negativos: 1- O componente gramatical que marca se a palavra está no feminino ou nâo, que coloca na grafia a condiçâo biológica que reduz as mulheres em detrimento do masculino; 2 - A metáfora do artigo como um item disponível à venda, a mulher como mercadoria, objeto de barganha em campanhas publicitárias e lojas em liquidaçấo, itens de consumo que ditam normas, padrōes e pasteurizam mulheres como se todas fossem iguais. Nesse sentido a mulher aparece no lugar do "outro", do subalterno, daquele que é objetificado no discurso de quem detém o espaço simbólico do direito à fala; 3 - Pode ainda configurar os artigos de revistas, aqui representadas pelo verso "publicado na página 5 das novas, 
cláudias, caprichos, e tititis", que săo utilizados na história da sociedade como reguladores da conduta feminina, desde a mais tenra idade até a vida adulta, novamente alienando a mulher e a colocando no espaço privado da disciplina e da domesticaçăo; 4 - Por fim, ao trazer a expressấo "Leia Maria da Penha", Luiza Romăo evidencia a necessidade de se tratar dentro da obra poética de questôes de ordem social e política, que deflagram os mais diversos crimes cometidos contra as mulheres.

Ainda que a leia Maria da Penha tenha procurado endurecer a puniçấo dos casos de feminicídio e violência doméstica, como exposto no capítulo anterior, esse tipo de violência ainda é subnotificada. Além disso, a justiça machista e condescendente, além da vergonha e da culpa dificultam os acessos a dados e números que espelhem de fato a realidade. Conforme a pesquisa Violência doméstica e familiar contra a mulher ${ }^{10}: 27 \%$ das mulheres entrevistas que já sofreram algum tipo de violência náo denunciaram seus agressores e nem pediram ajuda; $77 \%$ das mulheres entrevistas dizem conhecer pouco a leia Maria da Penha; 26\% delas acredita que a leia protege as mulheres; 53\% dessas mulheres acreditam que a lei protege em partes. Infelizmente leis e estatísticas năo sấo capazes de proteger mulheres das violências de gênero e, por isso, o poema evidencia que nem os artigos da Lei Maria da Penha săo capazes de o universo feminino e as duras lutas travadas cotidianamente.

Nenhuma dessas perspectivas sâo capazes de vislumbrar o que é o feminino, elas săo ferramentas, algumas vezes usadas contra as mulheres para justificar as mais variadas barbaridades, em outras insuficientes para protegê-las. Por fim, Luiza Romáo deixa evidente que em contrapartida com essas assertivas, ser mulher está na açâo:

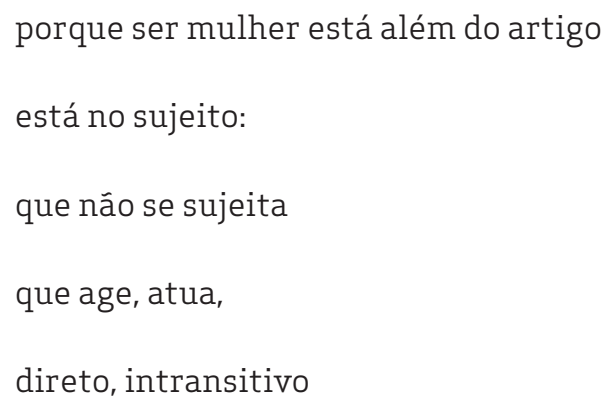

O corpo feminino parece rechaçar as normas de conduta vigentes, transbordando o individual no coletivo, ao passo que representa as mulheres que que nâo se deixam

10 A pesquisa Violência doméstica e familiar contra a mulher pode ser acessada na íntegra no endereço eletrônico: http://www.justicadesaia.com.br/wp-content/uploads/2017/06/VIOLÊNCIA-DOMÉSTICAE-FAMILIAR-CONTRA-A-MULHER-2017.pdf . Acesso em 25 set 2017. 
assujeitar, visto que aqui está "investido como direito das minorias e de um desejo de liberdade, tornando-se o 'lugar de soberania do sujeito'. Dentro dessa lógica, o traço corporal traduz a independência do indivíduo em relaçáo ao social" (NOVAES, 2011, p. 483; grifos da autora).

Usando os elementos gramaticais, o eu lírico toma posse do discurso, reconhece seu lugar de subalterno e o repele, pratica a açăo (ao passo que se faz sujeito) e ao intitular-se "direto, intransitivo" rejeita complementos, em uma metáfora que evidencia que a mulher năo precisar estar atrelada à figura de um homem para existir, ela basta por si. Praticando a açấo, esse sujeito "independente de gênero, número e grau" fragmenta o eu singular e o transborda em um eu coletivo, que conclama as demais mulheres a assumirem também suas vozes e corpos e se colocarem no mundo, por meio da empatia, em diálogo e postura combativa frente às opressôes vividas.

Se o corpo acumula memória e por meio da escrita nos legitima a falar, a voz agora empregada no papel assume a postura combativa e convida outras mulheres que passaram por situaçōes de violência a se unirem no rompimento do silêncio. A poesia torna-se um espaço em que circulam economias afetivas compartilhadas e que vislumbra a possibilidade de reconfiguraçăo e reescrita de um futuro, livre das opressóes contra mulheres.

O processo histórico que demonizou a mulher bruxa, desobediente e insubmissa também a converteu no modelo de feminilidade pautado "na mulher e esposa ideal passiva, obediente, parcimoniosa, casta, de poucas palavras e sempre ocupada com suas tarefas" (FEDERICI, 2017, p. 205). No poema esse modelo é representado pela "máe gentil" evocada pelo hino nacional, que revela estruturas patriarcais e modelos de sociedade caducos e sem representatividade. O poema traz figuras femininas marcadas pela violência, e que por isso sâo reais, falhas, complexas e múltiplas que ressignificam o que é ser mulher ao evidenciar seus corpos e vozes, por meio do eu lírico, e năo aceitar mais a abjeçāo imposta.

\section{CONSIDERAÇÕES FINAIS}

O poema de Luiza Romăo ora analisado traz a necessidade de falar, de deflagrar a denúncia das mazelas vividas por mulheres, principalmente as que sofrem algum tipo de precariedade social, seja por questôes de classe e/ou violência de gênero. Os versos livres, a linguagem ácida e dura, muito além da questāo panfletária deflagram a ruptura com certos mitos, tabus e normas de condutas sociais que, em virtude de teorias biologizantes e reducionistas, silenciam as mulheres, sobretudo as oriundas de grupos minoritários.

A potência da escrita de Luiza Româo a inscreve num discurso de resistência e reinvindicaçấo muito próprio da literatura marginal-periférica e dos movimentos dos slams, dos quais a autora faz parte. A autora deflagra um espaço simbólico em que a coletividade de mulheres pauta um projeto estético e poético de luta em que a representaçăo feminina náo aceita mais o lugar abjeto e subalterno em que foi relegado na sociedade, năo mais aceita ser objeto do discurso masculino e sim sujeito de seus próprios discursos e açōes.

Num processo que primeiro desconstrói para depois reconstruir, a imagem da 
mulher dócil, pacata e submissa, cujo corpo é controlado socialmente, é transformada e dá lugar a uma representação mais real e emancipada, de uma mulher forte e trabalhadora, cuja voz é construída por versos que rompem silêncios e espaços de dor.

O corpo em performance funda seu lugar no mundo, espaço de reinvindicaçáo da voz coletiva de mulheres empoderadas e conscientes, que năo se deixam assujeitar. Luiza Romáo, de certa forma, resgata a figura da bruxa, mulher profana e desobediente que transgride padrôes, que se reapropria da rua, de sua fisicalidade. Uma mulher que confronta outros corpos para que juntos e infestados viralizem os sistemas, armados de tiros certeiros, motoloves de saliva e poesia. 


\section{REFERÊNCIAS}

AHMED, Sara. Feminist Futures. In: EAGLETON, Mary. A Concise Companion to Feminist Theory. London: Blackwell, 2003. p. 236-254.

BEAUVOIR, Simone de. O segundo sexo. Traduçăo Sérgio Milliet. Rio de Janeiro: Nova Fronteira, 2009.

BOURDIEU, Pierre. A dominaçâo masculina. Traduçăo Maria Helena Kühner. 2 ed. Rio de Janeiro: Bertrand Brasil, 2002.

BRAH, Avtar. Diferença, diversidade, diferenciaçăo. Cadernos Pagu. Campinas, n. 26, p. 329-376, jan-jun 2006. Disponível em: http://www.scielo.br/scielo.php?script=sci_arttext\&pid=S0104-83332006000100014\&Ing=en\&nrm+iso7tlng=pt. Acesso em: 05 jun. 2017.

D'ALVA, Roberta. Teatro hip-hop: a performance poética do ator-MC. Sáo Paulo: Perspectiva, 2014.

ÉSQUILO. Oréstia: Agamêmnon, Coéforas, Eumênides. Rio de Janeiro: ZAHAR, 2010.

EURÍPEDES. Medeia. São Paulo: Editora 34, 2010.

FEDERICI, Silvia. Calibă e a bruxa: mulheres, corpo e acumulaçăo primitiva. Traduçăo Coletivo Sycorax. Sâo Paulo: Elefante, 2017.

GROSZ, Elizabeth. Corpos Reconfigurados. Cadernos Pagu, Campinas, n. 14, p. 45-86, jan-jun 2000. Disponível em: https://periodicos.sbu.unicamp.br/ojs/index.php/cadpagu/ article/view/8635340. Acesso em: 31 ago. 2017.

LOURO, Guacira Lopes. Pedagogias da Sexualidade. In: , Guacira Lopes (Org.). 0 corpo educado: Pedagogias da sexualidade. Belo Horizonte: Autêntica Editora, 2010, p. 7-34.

NOVAES, Joana Vilhena. Beleza e feiura: corpo feminino e regulaçăo social. In: PRIORE, MARY DEL; AMANTINO, Márcia (orgs.) História do corpo no Brasil. Sáo Paulo: Editora Unesp, 2011, pp. 477-506.

PERROT, Michelle. Os silêncios do corpo da mulher. Traduçăo Luiz Antônio Oliveira de Araújo. In: MATOS, Maria Izilda Santos de, SOIHET, Rachel (orgs). O corpo feminino em debate. Săo Paulo: Editora da Unesp, 2003. pp. 13-28.

ROMAO, Luiza. Coquetel Motolove. Săo Paulo: Selo Burro, 2014.

SOLNIT, Rebecca. A mâe de todas as perguntas: reflexóes sobre os novos feminismos. Traduçấo Denise Bottmann. Sáo Paulo: Companhia das letras, 2017.

SHOWALTER, Elaine. Anarquia sexual: sexo e cultura do fin de siècle. Traduçăo Waldéa Barcellos. Rio de Janeiro: Rocco, 1993. 
SHOWALTER. Elaine. Histéricas: a histeria e a mídia moderna. Traduçăo Heliete Vaitsman. Rio de Janeiro: Rocco, 2004.

TIBURI, Márcia. Aborto como metáfora. In: RODRIGUES, Carla; BORGES, Luciana; RAMOS, Tânia Regina Oliveira (Orgs.). Problemas de gênero. Rio de Janeiro: Funarte, 2016, pp. 135-147 